Original Research Paper

\title{
Penyuluhan dan Demonstrasi Deteksi Dini Tumor Payudara dengan Metode 'SADARI' pada Ibu-ibu RT 09 Pagesangan Mataram
}

\author{
Ida Ayu Eka Widiastuti ${ }^{1}$, Rifana Cholidah ${ }^{2}$, Ika Primayanti ${ }^{3}$ \\ ${ }^{1}$ Department of Physiology, Faculty of Medicine Universitas Mataram, Mataram, Indonesia \\ ${ }^{2}$ Department of Nutrition, Faculty of Medicine Universitas Mataram, Mataram, Indonesia \\ ${ }^{3}$ Department of Public Health, Faculty of Medicine Universitas Mataram, Mataram, Indonesia
}

DOI: https://doi.org/10.29303/jpmpi.v3i2.567

Sitasi:. Widiastuti, I. A. E., Cholidah, R., \& Primayanti, I. (2020). Penyuluhan dan Demonstrasi Deteksi Dini Tumor Payudara dengan Metode 'SADARI' pada Ibu-ibu RT 09 Pagesangan Mataram. Jurnal Pengabdian Magister Pendidikan IPA, 3(2)

\author{
Article history \\ Received: 25 Oktober \\ Revised: 15 Nopember \\ Accepted: 29 Desember
}

*Corresponding Author: Ida Ayu Eka Widiastuti, Faculty of Medicine Universitas Mataram, Mataram, Indonesia;

Email: ayueka@unram.ac.id

\begin{abstract}
One of the non-communicable diseases which is quite high in number is malignancy/cancer. The type of cancer that many women suffer and fear is breast cancer. Breast cancer is a cancer with the highest percentage of new cases $(43.3 \%)$ and the highest percentage of death (12.9\%) in women in the world. Based on the 2013 Basic Health Research data, the prevalence of breast cancer in Indonesia has reached 0.5 per 1000 women. Preventive efforts are needed by early detection of breast tumors / malignancies. The purpose of this activity was to increase the knowledge of the mothers of RT 09 Kelurahan Pagesangan Mataram about simple ways to independently detect breast tumors and to enable participants to independently carry out breast examination using the BSE (Breast Self-Examination) method. The method of implementing the activity includes counseling, demonstration of breast examination skills using the BSE method and question and answer. The indicator of the success of the activity is assessed from the increase in the knowledge of the mother before and after the activity by analyzing the results of the pre and posttest in the form of 10 short questions. This activity was carried out on August 20, 2019, attended by 27 women from RT 09 Kelurahan Pagesangan Mataram. There was an increase in participants' knowledge before and after the activity, based on the mean pre and posttest scores, namely 25, 93 and 71.85 respectively. Counseling and demonstration of breast examination using the BSE method was able to increase the knowledge and understanding of the mothers of RT 09 Kelurahan Pagesangan Mataram as a simple early detection of tumors / malignancies in the breast.
\end{abstract}

Keywords: Breast Cancer, Early Detection, Breast Examination, BSE Method

\section{Pendahuluan}

Salah satu penyakit tidak menular yang jumlahnya cukup tinggi adalah keganasan/kanker. Pada tahun 2017 ini diprediksikan hampir 9 juta orang meninggal di seluruh dunia akibat kanker dan akan terus meningkat hingga 13 juta orang per tahun di 2030. Di Indonesia, prevalensi penyakit 
kanker juga cukup tinggi. Menurut data Riskesdas 2013, prevalensi kanker di Indonesia adalah 1,4 per 100 penduduk atau sekitar 347.000 orang. Sementara itu jika melihat data BPJS Kesehatan, terdapat peningkatan jumlah kasus kanker yang ditangani dan pembiayaannya pada periode 2014 - 2015 (Kementerian Kesehatan RI, 2017).

Kanker yang merupakan salah satu penyakit tidak menular ditandai dengan pertumbuhan sel tidak normal, yaitu pertumbuhan sel terjadi secara terus-menerus dan tidak terkendali sehingga dapat merusak jaringan sekitarnya. Sel kanker dapat menjalar ke tempat yang jauh dari asalnya yang disebut metastasis, baik melalui pembuluh darah (hematogen) maupun pembuluh limfe (limfogen). Sel kanker bersifat ganas dapat berasal atau tumbuh dari setiap jenis sel di tubuh manusia (Depkes RI, 2009). Jenis kanker yang banyak diderita dan ditakuti oleh perempuan adalah kanker payudara. Pada umumnya kanker payudara menyerang kaum wanita, kemungkinan menyerang kaum laki-laki sangat kecil yaitu 1:1000 (Mulyani, 2013 dalam Brilliana, Arafah, dan Notobroto, 2017).

Berdasarkan estimasi Globocan, International Agency for Research on Cancer (IARC) tahun 2012, kanker payudara adalah kanker dengan persentase kasus baru tertinggi $(43,3 \%)$ dan persentase kematian tertinggi $(12,9 \%)$ pada perempuan di dunia. Berdasarkan data Riset Kesehatan Dasar tahun 2013, prevalensi kanker payudara di Indonesia mencapai 0,5 per 1000 perempuan (Kemenkes RI, 2015). Berdasarkan data Subdit Kanker Direktorat Pengendalian Penyakit Tidak Menular (PPTM) Kemenkes RI terdapat sekitar 36.761.000 perempuan seluruh Indonesia yang berumur 30-50 tahun. Sejak tahun 2007-2013 deteksi dini yang telah dilakukan oleh perempuan sebanyak
644.951 orang $(1,75 \%)$ dengan penemuan suspek benjolan (tumor) payudara 1.682 orang (2,6 per 1000 penduduk) (Kemenkes RI, 2014).

Melihat data-data kejadian tumor/kanker payu dara di atas, maka diperlukan upaya promotif dan preventif dengan melibatkan masyarakat seluasluasnya. Pencegahan kanker payudara difokuskan pada deteksi tumor stadium awal yang biasanya berukuran kecil. SADARI (Pemeriksaan Payudara Sendiri) merupakan salah satu metode deteksi dini untuk menemukan kanker payudara stadium awal. Metode ini akan lebih efektif jika dilakukan sedini mungkin. SADARI dilakukan setiap kali selesai menstruasi yaitu hari ke-7 sampai ke-10 terhitung hari pertama haid, karena pada saat ini pengaruh hormon estrogen dan progesteron sangat rendah dan jaringan kelenjar payudara saat itu tidak tidak membengkak sehingga lebih mudah meraba adanya tumor ataupun kelainan pada payudara (Brilliana, Arafah, dan Notobroto, 2017).

Agar para ibu dapat melakukan tindakan pencegahan terhadap kanker/tumor payudara secara benar, sehingga tujuan dari tindakan deteksi dini tercapai, maka diperlukan pemahaman yang benar dan keterampilan yang memadai. Penyuluhan dan demonstrasi dapat menjadi salah satu metode yang efektif untuk mencapai tujuan dimaksud.

\section{Metode}

Kegiatan pengabdian masyarakat ini dilaksanakan dengan menggunakan metode (1) penyuluhan; materi penyuluhan disampaikan dengan menggunakan flipchart, gambar, Materi yang disampaikan adalah: 
pengertian tentang tumor, jenis-jenis tumor pada payudara, faktor risiko terjadinya tumor/keganasan, cara melakukan deteksi dini, dan pengenalan tentang terapi tumor payudara. Sebelum dan sesudah dilakukan penyuluhan diberikan soal pre dan posttest yang wajib dikerjakan oleh ibu-ibu peserta penyuluhan, (2) demonstrasi keterampilan pemeriksaan payudara; keterampilan pemeriksaan payudara dengan menggunakan metode SADARI didemonstrasikan dengan menggunakan manikin payudara yang selanjutnya para peserta diberikan kesempatan untuk melakukan keterampilan pemeriksaan payudara dimaksud dengan dibimbing oleh tim,dan (3) tanya jawab; memberikan kesempatan kepada peserta untuk memahami dengan lebih baik materi yang disampaikan, mengkonfrmasi hal-hal yang masih kurang dipahami.

\section{Hasil dan Pembahasan}

Kegiatan penyuluhan dan demonstrasi deteksi dini tumor payudara dengan menggunakan metode "SADARI" pada ibuibu RT 09 Kelurahan Pagesangan Mataram dilaksanakan pada tanggal 20 Agustus 2019. Jumlah peserta yang hadir pada kegiatan pengabdian ini adalah 27 orang. Kegiatan yang berlangsung selama kurang lebih 2 jam ini terdiri dari 3 subkegiatan, yaitu: pre dan posttest, penyampaian materi penyuluhan oleh tim penyuluh, dan demonstrasi pemeriksaan payudara dengan metode SADARI.

Soal pre dan posttes terdiri dari 10 nomor dengan jenis soal isian singkat. Dari analisis hasil pretest diperoleh rerata nilai 25,93. Setelah ibu-ibu mengikuti materi penyuluhan, pengetahuan ibu-ibu peserta tentang tumor payudara, pencegahan, dan deteksi dini meningkat, dilihat dari analisis hasil posttes dengan rerata nilai 71,85.

Materi penyuluhan diberikan selama kurang lebih 30 menit. Materi penyuluhan yang diberikan meliputi: definisi tumor payudara, cara membedakan tumor jinak dan ganas secara sederhana, waktu yang tepat untuk melakukan pemeriksaan payudara, dan prosedur melakukan pemeriksaan payudara dengan metode SADARI. Materi disampaikan secara lisan dengan menggunakan komunikasi 2 arah, dimaksudkan untuk mengakomodir kekurangpahaman peserta terhadap materi yang disampaikan dan membuka kesempatan seluas-luasnya kepada peserta untuk mendapatkan pengetahuan yang memadai tentang tumor payudara.

Demonstrasi pemeriksaan payudara dengan menggunakan metode SADARI dilaksanakan setelah tim pengabdian masyarakat menyampaikan materi penyuluhan. Kegiatan ini berlangsung sekitar 20 menit. Demonstrasi pemeriksaan payudara dilakukan pada manikin payudara milik Laboratorium Keterampilan Medik Fakultas Kedokteran Universitas Mataram. Tim menyampaikan prosedur pemeriksaan langkah demi langkah, mulai dari persiapan hingga pelaksanaan. Kegiatan diakhiri dengan sesi tanya jawab, baik terkait materi penyuluhan maupun teknik pemeriksaan payudara. Antusiasme peserta cukup baik. Hal ini dapat disimpulkan dari cukup banyaknya jumlah penanya. Ada 8 peserta yang menyampaikan pertanyaan. Materi yang ditanyakan variatif, namun sebagian besar pertanyaan mengarah pada diagnosis tumor payudara dan detail pemeriksaan payudara dengan metode SADARI, serta tindak lanjut apabila pada saat pemeriksaan mereka menemukan hal yang abnormal.

Kegiatan pengabdian masyarakat yang dilakukan oleh tim pengabdian ini menyasar ibu-ibu di Lingkungan RT 09 Kelurahan Pagesangan Mataram. Hampir semua ibu RT 09 ini adalah wanita usia produktif. Hal utama yang ingin dicapai dalam kegiatan ini adalah untuk mentransfer ilmu tentang kesehatan payudara, khususnya dalam deteksi dini tumor payudara dan memberikan 
bekal keterampilan tentang langkah-langkah atau prosedur pemeriksaan payudara dengan menggunakan metode SADARI sebagai langkah sederhana untuk deteksi dini tumor payudara.

Berdasarkan hasil analisis dari nilai pre dan posttest yang diberikan kepada peserta, terlihat adanya peningkatan pengetahuan peserta terkait materi penyuluhan yang telah disampaikan, yaitu dari rerata nilai 25,93 menjadi 71,85. Salah satu indikator keberhasilan kegiatan penyuluhan suatu topik adalah peningkatan pengetahuan peserta penyuluhan, yang salah satunya dapat diukur secara sederhana melalui pemberian soal/tes sebelum dan setelah penyampaian materi.

Materi penyuluhan yang diberikan secara sistematis dengan menggunakan bahasa yang mudah dipahami dan meminimalisir bahasa medis atau jika istilah medis tidak dapat dihindari, maka peserta diberikan penjelasan sederhana terkait istilah medis yang dimaksud. Sebagai materi pendahuluan disampaikan bahwa kanker payudara adalah kanker dengan persentase kasus baru tertinggi $(43,3 \%)$ dan persentase kematian tertinggi $(12,9 \%)$ pada perempuan di dunia, berdasarkan estimasi International Agency for Research on Cancer (IARC) tahun 2012. Dengan menyampaikan fakta yang ada peserta didorong untuk memiliki rasa ingin tahu yang lebih besar untuk mengikuti materi-materi selanjutnya. Penyuluhan diakhiri dengan materi tentang langkah-langkah atau prosedur pemeriksaan payudara dengan metode SADARI. Setiap pergantian subtopik penyuluhan, tim penyuluh memberikan kesempatan kepada peserta untuk menyampaikan pertanyaan, walaupun tidak banyak yang memanfaatkan kesempatan ini. Peserta pada akhirnya menggunakan waktu yang disediakan setelah penyampaian materi penyuluhan untuk bertanya terkait hal-hal yang masih kurang dipahami.
Kegiatan demonstrasi difokuskan pada detil pemeriksaan di tiap-tiap langkah pemeriksaan. Prosedur pemeriksaan dengan metode SADARI terdiri dari 6 langkah. Adanya manikin payudara sangat memudahkan tim untuk memberikan pemahaman kepada peserta terkait keterampilan pemeriksaan payudara dimaksud. Kesempatan tanya jawab yang kedua diberikan kepada peserta setelah tim selesai mendemonstrasikan keenam langkah pemeriksaan dengan metode SADARI. Seperti halnya dengan kesempatan pertama, pada kesempatan tanya jawab yang kedua ini, peserta melontarkan pertanyaan yang cukup kritis.

\section{Kesimpulan}

Kegiatan penyuluhan dan demonstrasi pemeriksaan meningkatkan pengetahuan dan pemahaman peserta tentang deteksi dini tumor payudara dengan metode SADARI.

\section{Ucapan Terima Kasih}

Penulis mengucapkan terima kasih kepada Ketua RT 09 dan ibu-ibu RT 09 Kelurahan Pagesangan Mataram atas dukungannya sehingga kegiatan pengabdian ini dapat terselenggara dengan baik.

\section{Daftar Pustaka}

Brilliana, R.A., Arafah, Notobroto, H.R., 2017. Faktor yang Berhubungan dengan Perilaku Ibu Rumah Tangga Melakukan Pemeriksaan Payudara Sendiri (SADARI). The Indonesian Journal of Public Health, Vol. 12 No. 2, pp. 143-153. Available at: https://e-

journal.unair.ac.id/IJPH/article/view/ 7589 [Diakses pada 12 Februari 2019].

Departemen Kesehatan Republik Indonesia. 2009. Sistem Kesehatan Nasional. Jakarta. 
Globocan. 2012. Estimated Cancer Incidence, Mortality, Prevalence and Disabilityadjusted life years (DALYs) Worldwide in 2008. IARC Cancer Base No. 11.

Kementerian Kesehatan Republik Indonesia, 2017. Kementerian Kesehatan Ajak Masyarakat Cegah dan Kendalikan Kanker. Jakarta: Kemenkes RI. Available at: http://www.depkes.go.id/article/print /17020200002/kementeriankesehatan-ajak-masyarakat-cegahdan-kendalikan-kanker.html [Diakses pada 12 Februari 2019].

Kementerian Kesehatan Republik Indonesia, 2012. Penyakit Tidak Menular. Jakarta: Pusdatin Kemenkes RI. Available at: http://www.pusdatin.kemkes.go.id/ar ticle/view/13010200029/penyakittidak-menular.html [Diakses pada 12 Februari 2019].

Kementerian kesehatan Republik Indonesia. 2014. Pusat Data dan Informasi. Jakarta.

Kementerian kesehatan Republik Indonesia. 2015. Pusat Data dan Informasi (Stop Kanker) Jakarta 